2016

\title{
Hobby Lobby, Birth Control, and Our Ongoing Cultural Wars: Pleasure and Desire in the Crossfires
}

Robin West

Follow this and additional works at: https://scholarlycommons.law.case.edu/healthmatrix

Part of the Health Law and Policy Commons

\section{Recommended Citation}

Robin West, Hobby Lobby, Birth Control, and Our Ongoing Cultural Wars: Pleasure and Desire in the Crossfires, 26 Health Matrix 67 (2016)

Available at: https://scholarlycommons.law.case.edu/healthmatrix/vol26/iss1/6

This Symposium is brought to you for free and open access by the Student Journals at Case Western Reserve University School of Law Scholarly Commons. It has been accepted for inclusion in Health Matrix: The Journal of Law-Medicine by an authorized administrator of Case Western Reserve University School of Law Scholarly Commons. 


\title{
Hobby Lobby, Birth Control, and Our Ongoing Cultural Wars: Pleasure and Desire in the Crossfires
}

\author{
Robin West
}

Contents

INTRODUCTION .67

I. The Natural Lawyers' Brief Against Birth Control .71

II. Is Procreative Marital Sex an Intrinsic Good? One

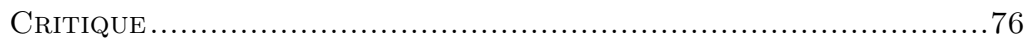

III. The SeXual-Libertarian Brief for Birth Control .....................89

IV. Is Autonomous Sex an Intrinsic Good? One Critique.................95

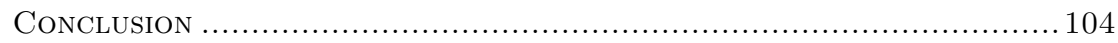

\section{INTRODUCTION}

Birth control has re-emerged as a political, legal and constitutional conundrum-maybe obsession-echoing its first such emergence fifty years ago, in the middle of the 1960s. Underlying the legal battles culminating in the Hobby Lobby ${ }^{1}$ decision from the Supreme Court's 2014 term, is a "culture war" that features familiar antagonisms - antagonisms that some of us might have thoughtwrongly - had abated - that first rose to constitutional prominence in Griswold v. Connecticut ${ }^{2}$ and Eisenstadt v. Baird, ${ }^{3}$ in 1965 and 1972 respectively. There is, though, a major difference between the cultural, legal and constitutional wars around birth control of the 1960s and our contemporary birth control wars, which has gone relatively unnoticed at least in the legal literature. By the end of that decade, the two major sides to the birth control wars had converged on a shared understanding of what I will refer to as the "social meaning," or point, of birth control; where they differed, of course, was over its value. But they more or less agreed on what birth

$\dagger$ Frederick J. Hass Professor of Law and Philosophy, Georgetown University Law Center.

1. Burwell v. Hobby Lobby Stores, Inc., 134 S. Ct. 2751 (2014).

2. Griswold v. Connecticut, 381 U.S. 479 (1965).

3. $\quad$ Eisenstadt v. Baird, 405 U.S. 438 (1972). 
control is. For both groups, birth control was understood to be a group of technologies that would artificially prevent or interrupt conception, and which, by so doing, would allow women to control their own fertility, and would allow heterosexual men and women to enjoy a sexual liberty unconstrained by anxiety or fears of conception. ${ }^{4}$ It would do other things as well. It would, for example, enhance the health of some women, particularly those who had already had multiple pregnancies, and for whom an additional pregnancy might be dangerous or life threatening. ${ }^{5}$ And, it would facilitate some degree of family planning by married couples seeking to control the spacing and size of their families. ${ }^{6}$ But all participants in those earlier birth control wars concurred that birth control, and particularly the newly invented and highly effective pill, would primarily allow women, whether married or not, much greater control of fertility, and would permit all heterosexuals much greater sexual liberty.

That social meaning, and certainly the consensus around it, has virtually disappeared from our current legal debates about access to birth control, and the existence or scope of claimed exemptions from various duties to provide insurance that covers it. We hear virtually no mention of it, either in the Hobby Lobby decision itself or in our debates regarding it. The majority opinion in Hobby Lobby makes no mention whatsoever of either the control of fertility or the liberation of sexual expression as intrinsic to the point of birth control, and even Justice Ginsburg's dissent contains only one brief reference to the control of fertility, and the importance of that control to women's equality, ${ }^{7}$ and no references at all to sexual expression, as part of birth control's value. The scholarly literature on Hobby Lobby both preceding the decision and in its wake has followed suit. Again, save the occasional article in the popular press, there is virtually no discussion in the sizeable cottage industry of Hobby Lobby legal

4. For a thorough legal history of the movement toward constitutionalizing a right to use birth control, see generally DAVID J. GARROW, LiBERTY and Sexuality: The Right to Privacy and the Making of Roe V. WADE (1998). For a social and political history of the movement for access to birth control, see Linda Gordon, The Moral Property of Women: A History of the Politics of Birth Control in America vii-viii (2007).

5. Garrow, supra note 4, at 94-95; GORDON, supra note 4, at 290-91.

6. This was the use of birth control emphasized and explicitly protected in Griswold. See Griswold, 381 U.S. at 503.

7. Hobby Lobby Stores, Inc., 134 S. Ct. at 2751, 2787 (2014) (Ginsburg, J., dissenting). 
commentary, ${ }^{8}$ and rarely even an acknowledgement, of what birth control $i s$ for the vast majority of users and objectors both: for many women, a means of limiting fertility, whether or not a pregnancy would be health or life threatening, and for perhaps an even larger number of men and women both, a way of facilitating sexual liberty, free of both the anxiety and the risks of reproduction.

Nor do we hear much of the arguments for or against birth control that presuppose that understanding of birth control's point, in the legal, cultural and political discussions that have surrounded Hobby Lobby. We don't hear much, for example, in this round of battles over birth control, of the virtues or vices of our changing demographics as family sizes shrink, or of the value of the entry of women into the workplace, prompted in part by their control of their own fertility, which is in turn facilitated by birth control, or of the greater participation of large numbers of men in parenting their young children that is tied to the same social developments. We don't hear much of the lack of censure or stigma attached to the status of either childlessness or illegitimacy. We are not asked, in our current legal and constitutional debates, to imagine the difficulties or unfairness of lives consumed by a cycle of continual and unwanted pregnancies, breastfeeding, and the raising of small children, occupying for many the course of an entire adult life, from the onset of menstruation to death, much less of lives severely shortened by that fate, rather than the reproductive lives so many of us enjoy, courtesy of birth control: lives punctuated by the arrival of much wanted children occupying a central part of a life, but a life that is also occupied by work, leisure and adult civic and cultural pursuits. We don't hear Loretta Lynn's or Matt McGinn's strong country voices: "The pill, the pill/ I'm pining for the pill/ I'll never have anymore/ because they're going to bless the pill"9 - they were wrong on that last part - widely credited by health organizations with having done more to educate rural women in the 1970s and 1980s on their reproductive options than any

8. Much of the progressive commentary on Hobby Lobby has focused not on the ACA per se, but on the weaknesses and vagueness in the Religious Freedom Restoration Act, and the result oriented decision making which the act prompts. See, e.g., Ira Lupu, Hobby Lobby and the Dubious Enterprise of Religious Exemptions, 38 HARV. J.L. \& GENDER 35, 35 (2015).

9. Matt McGinn, The Pill, on Honesty Is Out Of the Fashion (Transatlantic XTRA 1968); Pete Seeger, The Pill, on Pete Seeger: A Link In the Chain (Columbia/Legacy 1996); Loretta Lynn, The Pill, on BACK TO THE COUNTRY (MCA Records 1972) (lyrics differ slightly: "But all I've seen of this old world/ Is a bed and a doctor bill... Yeah I'm makin' up for all those years/ Since I've got the pill"). 
education or public health campaign before or since. ${ }^{10}$ We hear even less - we don't hear anything really - of the value of the sexual expression that is facilitated by the liberation of heterosexual intercourse from the risks and concerns of unwanted pregnancies. On the other side of the ledger, we don't hear much of the moral wrongs that birth control either constitutes or facilitates, according to its socially conservative critics. We are not being asked, in this round of our debates, to try to imagine, or at least understand, what's wrong with a sexuality in which the body is used as an instrument for pleasure untied to the particular moral end of conception, or of the host of social harms, from the difficulties of unwed parenthood to the spectacle of a sex-saturated popular culture thrust on the interested and uninterested alike, that might emanate from that use. To sum this up, we don't hear much, if anything, of the notion that birth control, again precisely because it facilitates the control of fertility and promotes sexual liberty, is either a boon to mankind for its contribution to women's equality or health, free sexual expression, or family planning, or a dire threat, because of its destruction of the nexus of family, marriage, sexuality and conception, the belief to which it gives rise of a false equivalence of sexuality with sport or expression or play, or its facilitation of greater rather than lesser male control, commodification and exploitation of female sexuality.

This paper seeks to reverse this trend, simply by entering the breach. In the four sections that follow, I first briefly examine, and then criticize, each of two of the major arguments - which are by no means the only arguments - that I believe have largely motivated opposition to birth control, on the one side, and support of its use on the other, for at least the last half-century, and the conception of heterosexual morality on which each of these two arguments depends. In the first two sections, I will take up and then criticize what I will call the "neo-natural lawyers' argument" against the use of birth control. In the third and fourth sections, I look at and criticize a "sexual-libertarian" (hereafter, sometimes, "libertarian" for short) argument for the use of birth control. In both sections, my critical focus will be not only on the competing arguments against or for birth control put forward by neo-natural laws and sexual libertarians respectively, but also on the competing conceptions of heterosexual morality that underlie each of the two sides' arguments.

My conclusion is that behind the constitutional veil of privacy protected by Griswold and Eisenstadt and celebrated by sexual libertarians, and behind the legal exemption recognized by Hobby

10. Spotlight Exhibit: Loretta Lynn, Rock HALl Blog, RocK \& Roll Hall OF FAME, (Feb. 10, 2012, 2:30 PM), http://rockhall.com/blog/post/7268_spotlight-exhibit-loretta-lynnwomen-who-rock/\#sthash.14ZxePrf.dpuf. 
Lobby and treasured by social conservatives and their neo- natural lawyer advocates, lie claims about the morality of heterosexuality and reproduction that deserve close examination and criticism. This paper seeks to at least put these arguments back on the table, along with the extremely problematic conceptions of heterosexual morality on which they rest and the political and psychic harms they may occasion.

\section{The Natural Lawyers' Brief Against Birth Control}

Without contraception, hetero, penetrative, vaginal-penile sexual intercourse relatively predictably leads to conceptions, many of which eventually blossom into full pregnancies and then live births. The contemporary neo-natural lawyers' argument against the use of birth control, first made in a papal encyclical in 1930, has centered on the claim that both those sexual acts and the blossoming of life to which they lead, and not the pleasure which may happily be their byproduct or the love they may cement, is the very point of marriage itself, at least when marriage is properly understood. ${ }^{11}$ Contrary to the Court's claim in Eisenstadt that a marriage is nothing more than a voluntary association of two individuals, ${ }^{12}$ a marriage, according to both

11. Casti Connubii, Encyclical of Pope Pius XI on Christian Marriage to the Venerable Brethren, Patriarchs, Primates, Archbishops, Bishops, and other Local Ordinaries Enjoying Peace and Communion with the Apostolic See [hereinafter 1930 Encyclical], reconfirmed in Pope Pius XII, Nature of Their Profession, Allocution to Midwives (1951) [hereinafter 1951 Encyclical], and in Encyclical Letter Humanae Vitae of the Supreme Pontiff Paul VI to his Venerable Brethren, Patriarchs, Primates, Archbishops, Bishops, and other Local Ordinaries Enjoying Peace and Communion with the Apostolic See, to the Clergy and Faithful of the Whole Catholic World, and to All Men of Good Will, on the Regulation of Birth (1968) [hereinafter 1968 Encyclical]. See generally Gerald Kelly, S.J., Contraception and the Natural Law, in Proceedings of the Eighteenth Annual Convention of the CAtholic Theological Society of America Contraception and NATURAL LAW 25 (1963). The author notes in this paper that a considerable portion of that paper is taken from Contemporary Moral Theology, II: Marriage Questions (Westminster, Newman Press 1963) by John C. Ford, S.J., and Gerald Kelly, S.J.. For the modern arguments see generally Robert P. George \& Gerard V. Bradley, Marriage and the Liberal Imagination, 84 GEO. L.J. 301, 301-320 (1995); Christopher Tollefson, The New Natural Law Theory, 10 LyCEUM 1, 7-8 (2008); Germain Grisez et al., Every Marital Act Ought to Be Open to New Life: Toward a Clearer Understanding, 52 THOMIST 365, 365 (1988).

12. Eisenstadt v. Baird, 405 U.S. 438, 453 (1972) ("Yet the marital couple is not an independent entity with a mind and heart of its own, but an 
contemporary neo-natural lawyers and the canonical authorities on which they rely, is a union of a man and woman for whom and between whom the spiritual and biological unity achieved through "sex of the reproductive form"-by which is meant heterosexual, noncontracepted, vaginal-penile, penetrative intercourse-both constitutes an act of spiritual friendship and an opening to the creation of life. That form of sex - and only that form of sex - makes the husband and wife one flesh: both biologically and spiritually whole. ${ }^{13}$ Sex that is of this reproductive form - or what they sometimes call "conjugal sex" is not simply a part of a healthy marriage, it is its very moral point. It is what marriage is for: marriage is that relationship within which heterosexual penetrative sex has this absolute moral value. It is that sex, then-not affection, not simple friendship, not mutual care and regard, not joint commitment to the welfare of each other, and not even the shared work of child-raising - which gives marriage its meaning and value likewise.

Birth control not only constitutes a form of endorsement of all the sex that is pursued for other ends, but it also both represents and facilitates the marital participants' willful splintering of marital sex from its moral end or goal. It strips marital sex and therefore marriage itself of its natural and moral purpose, which is the physical unity of marital partners in a sexual act of spiritual friendship that is open to conception and the eventual creation of new human life. When used by marital partners, birth control is thus doubly wrongful. Outside of marriage, of course, it carries additional societal harms and wrongs as well.

What has gone relatively unnoticed about this argument, perhaps by the natural lawyers themselves but certainly by the natural lawyers' legions of critics, is that the natural lawyers' brief against birth control, rests on not one, but two related but nevertheless distinct claims about sexual morality. The first claim might be called the "censorial claim": all sexual relations that are not of the "reproductive form" (marital, hetero, non-contracepted, vaginal-penile and penetrative), according to the natural lawyers, are immoral. The second claim, which is far less often examined and almost never criticized, is what I will call the natural lawyers' "valorizing claim": all sex that $i s$ of the reproductive form - sex that is hetero, vaginalpenile, penetrative, within marriage and, most important here, uncontracepted - is an unalloyed, natural, human, spiritual and intrinsic good. This second claim asserts, in effect, that the

association of two individuals each with a separate intellectual and emotional makeup.").

13. George \& Bradley, supra note 11, at 305. See generally Grisez et al., supra note 11, at 416 . 
reproductive form is a sufficient condition for moral sex: all marital sex that is of the reproductive form is a natural, human good. There are no further conditions to its value. The use of birth control therefore frustrates participation in what would otherwise be a morally praiseworthy, highly valorized, and intrinsically good act: sex within marriage of the reproductive form (hereinafter, for short, "sex of the marital form", or sometimes, where the usage would not be ambiguous, "marital sex").

The natural lawyers' brief against birth control then consists of two arguments, and they are quite separate: first, contracepted sex even within marriage, just like, and for the same reasons as, same sexsex, fornication, adultery, prostitution, and sex within marriage that is not of the reproductive form for some other reason (nonpenetrative, etc.), all of which they call alternately "recreational," "affective," "instrumental," or "pleasurable," is wrong. This follows from the censorial claim. But second, so long as it is marital, noncontracepted sex - sex that is open to the possibility of pregnancy - is a fundamental, unassailable human good. The use of birth control within marriage negates or frustrates participation in that human good. The second is a claim not about what sex is immoral and wrong, but rather, what sex is fundamentally and alwaysunconditionally-good: procreative sexual intercourse of the reproductive form within marriage. The use of birth control by married partners prevents what would otherwise be participation in this natural human good.

The natural lawyer's censorial claim - that only sex of the marital form is moral, or that all sex that is not of this form is immoral - has, perhaps needless to say, attracted a tidal wave of criticism by legal scholars as well as sexual ethicists, in large part because of the major implications it seems to entail that pertain to law (or, more accurately, its entailed implications that have in the recent past pertained to law, given a pre-Lawrence conception of the scope of the police power), including, but by no means limited to, its censorial stance toward birth control. ${ }^{14}$ First, of course, it immediately follows from the natural lawyers' censorial claim that "same-sex marriage" is oxymoronic and its provision by states and its new-found constitutional protection by the Supreme Court ${ }^{15}$ ill-advised: civil marriage is the legal institution the very point of which is to protect the social institution of marriage, which in turn and by definition

14. See, e.g., Stephen Macedo, Homosexuality and the Conservative Mind, 84 Geo. L.J. 261 (1995); Chai Feldblum, Gay Is Good: The Moral Case for Marriage Equality and More, 17 YALE J.L. \& FEMINISM 139 (2005).

15. Obergefell v. Hodges, 135 S.Ct. 2584 (2015) (holding that the constitution protects the right to enter into a same-sex marriage). 
exists so as to facilitate heterosexual, penetrative sex of the marital form, meaning that sex - penile-vaginal, penetrative and procreativewhich in form leads to conception. ${ }^{16}$ This is the argument that has been most criticized by courts, including now the Supreme Court, and commentators. ${ }^{17}$ Second, and as now countless commentators have argued, it follows from the natural lawyer's censorial claim that nonmarital sex in any form and toward any end, including all same-sex sex, contracepted or non-contracepted heterosexual sex between unmarried persons, or sex between partners of either or any gender that is motivated by a desire to cement feelings of long-lasting and deep love, is illicit. ${ }^{18}$ It thus denies the morality not only of gay sex that is sought solely for pleasure, or money, or prestige, but also of affective gay sex, meaning sex between same-sex partners who are committed to each other and to a long term or life-long relationship, whether or not they wish to civilly marry and whether or not they wish to have and raise children. ${ }^{19}$ Third, it follows from the natural lawyers' censorial claim that not only should only married heterosexual partners engage in sex, but married partners should engage in only that form of sex. Sex "of the right form" within marriage is a sacred comingling of the marital participants in a form of sexual intercourse that has a particular teleological purpose, to wit, conception. All other sex, including sex inside of marriage that is either contracepted or that is otherwise not of the right form (meaning, non penile-vaginal or non-penetrative), interrupts the moral link between marital sex and conception, thus stripping sex of any moral or religious purpose. It reduces it to an instrumental use of the body for nothing but base pleasure. This prong of the argument has of course also been subjected to criticism, including by both birth control advocates and sexual libertarians, from the nineteen twenties through the 1970 s. $^{20}$ In short, to sum the criticism, the natural

16. See George \& Bradley, supra note 11 , at 307.

17. See Obergefell v. Hodges, 135 S.Ct. 2584 (2015); Bostic v. Schaefer, 760 F.3d 352, 367-68 (4th Cir. 2014); Baskin v. Bogan, 766 F.3d 648, 661 (7th Cir. 2014); Kitchen v. Herbert, 755 F.3d 1193, 1210 (10th Cir. 2014); Goodridge v. Dep't of Pub. Health, 798 N.E.2d 941, 961 (Mass. 2003).

18. Macedo, supra note 14 , at 274-75.

19. Finnis argues for the latter, viewing the criminalization of gay sex unwise and unjust for traditionally liberal reasons.

20. For early twentieth century arguments focused on feminist campaigns against involuntary motherhood and the institutions of marriage and the Church, see The Public Writings and Speeches of Margaret Sanger, http://www.nyu.edu/projects/sanger/webedition/app/documents/show. php?sangerDoc=128167.xml; Margaret Sanger, No Gods, No Masters, in The Woman ReBel 1, 8, 16 (March 1914), 
lawyers' censorial condemnation of contracepted and non-vaginallypenetrative marital sex, as well as all extramarital and same-sex sex, rests on a view of sexuality, pleasure and love that seems untrue to the experience of vast numbers of married as well as unmarried people. For many married and unmarried partners alike in long term committed relationships, both same and opposite-sex, contracepted or non-penetrative sex is both moral and of great value: its value and its morality both lie in the pleasure it facilitates and the way in which it cements the partners' affection for each other. The same seems true, furthermore, for many people, in same sex and opposite sex relations of shorter duration, and again regardless of the type of sex in which the partners are engaged.

Common to almost all of the contemporary criticisms of the canonical and neo-natural lawyers' conception of heterosexual morality, however, has been the critics' focus on the Church's censorial claim. That is, the natural lawyers' secular critics have focused almost entirely on all of the sex that the natural lawyers morally condemn. What has gone almost entirely un-criticized, by contrast, and indeed almost unnoted, is what I've called above the natural lawyer's "valorizing claim": the claim that all marital sex of the marital form-ncontracepted, vaginal-penile, penetrative sex in marriage-is an intrinsic human and common good, or more briefly, that the marital form (which again includes the requirement that the sex be un-contracepted) is a sufficient condition for the goodness of sex. This second and much less examined claim regarding the absolute goodness of marital sex, rather than the badness of nonmarital, is at least as significant a part of the natural lawyers' brief against birth control, although it doesn't figure so centrally in their argument against homosexuality, which may be why it has gone relatively un-criticized. It is a gross misunderstanding and a serious diminution of the natural law view of human sexuality and of sexual morality to limit it to its censorial claim condemning the sex they view as immoral. Rather, the natural law view of sexuality, in its totality, also rests on the radically pro-sex claim that all noncontracepted sex of the marital form (including such sex between infertile couples, where the infertility is for natural reasons), and all the pregnancies to which that sex often leads, are good. Indeed, the

http://historymatters.gmu.edu/d/5084/. For late twentieth century arguments focused on sexual liberty, see DAVID A.J. RICHARDS, Resisting Injustice and the Ethics of Care in the Age of Obama: "Suddenly... All the Truth Was Coming Out" 4 (2013); Carol Gilligan \& David A.J. Richards, The DeEPening Darkness: Patriarchy, Resistance, AND Democracy's Future 4 (2009); David A.J. Richards, Women, Gays and the Constitution: The Grounds FOR FEMINISM AND GAY RIGHTS IN CULTURE AND LAW (1998). 
wrongness of birth control used within marriage (as contrasted to outside marriage) is precisely that it interrupts that form of morally praiseworthy sex by intentionally and artificially frustrating the possibility of conception. The wrongness of birth control, in other words, is not only that it facilitates immoral sex, but also that it frustrates otherwise morally exemplary procreative sex, which is the raison d'etre, and the very center of married life. It is this valorizing pro-sex claim of the natural lawyers, as well as the argument against birth control which it grounds, that has gone virtually unnoticed by the natural lawyers' contemporary critics.

As a consequence of the natural lawyers' critics' relative inattention to it, not only the natural lawyer's valorizing claim itself - that uncontracepted marital sex is an intrinsic human goodbut also the harms, particularly for married women, that this claim might engender have gone relatively unnoticed in the scholarly literature, although not, one might surmise, in married life itself. Critics have focused on and catalogued instead the harms caused by the censorial claim: the denial of the equal value and worth of samesex affective sex, the unnecessary censure of sexual expression, the dour and damning stance toward sexual pleasure both within and outside marriage, the sizeable social costs of criminalizing or censuring prostitution, fornication, or homosexuality, and of course the condemnatory stance toward same-sex couples and same-sex marriage. ${ }^{21}$ Critics have not looked at the harms that might be caused by the natural lawyers' valorizing pro-sex claim: that all uncontracepted sex within marriage that is of the marital form is an intrinsic human good. The legalistic black box created by the Religious Freedom Restoration Act, Hobby Lobby, and the debate surrounding that case, as described above, pushes those arguments and the harms they might cause all the further from public awareness. Those harms, though, are quite real, and they are utterly distinct and quite different from the harms caused by the censorship of pleasurable and affective sex. The next section tries at least to catalogue them.

\section{Is Procreative Marital Sex an Intrinsic Good? One CRitique}

What does the neo-natural lawyers' blanket moral celebration of all uncontracepted marital sex include? What falls within the category of the sex the natural lawyers celebrate, and might some of that laudatory celebration be misguided? Does it include, for

21. See generally George \& Bradley, supra note 11, at 311; Macedo, supra note 14 , at 275 . 
example, nonconsensual marital sex? It isn't at all clear. ${ }^{22}$ In their many elaborate definitions and descriptions of marital sex, and their constant iteration of the various conditions that sex must meet, in order for it to be moral and praiseworthy, "mutual consent" of the parties is rarely unambiguously included. Thus, Thomas Aquinas believed that married women have a positive duty to be sexually available to their husbands, and that to deny their husbands sexual access was sinful (and vice versa; men likewise have a duty to be sexually available to their wives). A woman who withholds sex from her husband, he believed, commits a greater sin than a man's rape of a stranger - the former is a sin against nature, while the latter is simply a sin against a person..$^{23}$ The Encyclical from 1930 that explains the Church's view of marriage, marital sex, and family life, doesn't noticeably soften this Thomistic stance. In the only reference I could find regarding the topic of consent, Pope Pius explains that periodic abstinence is an acceptable method of birth control, but only if both partners consent to it. Thus, presumably, the desire of only one party that the couple abstain from sex (in order to prevent conception) is not a sufficient grounds for abstaining: if one party wishes to abstain but the other party does not, the sex not only may happen but apparently should. ${ }^{24}$ To translate this into modern terms, a woman's "no," according to Pope Pius writing in the 1930s, is not by itself a sufficient reason to abstain from marital intercourse if her husband does not agree; the man has veto power. In the 1968 Encyclical on birth control, Pope Paul references apparently with some approval his understanding that "[m]en rightly observe" that for a man to impose sex on one's partner against "her condition or personal and reasonable wishes" is a wrong. ${ }^{25}$ Still, this observation about what "men rightly observe" is made only to suggest that anyone who so thinks should also see the immorality of having sex against the reasonable wishes of the Divine Creator-meaning, should also see the immorality of contracepted sex. One wonders, though, what might be the status of a sexual act imposed against a wife's unreasonable wishes. Nevertheless, at least by the 1960s, a married

22. As a legal matter, consent was not a condition of legal marital sex until the reforms of the 1980s began to result in the systematic removal, or at least trimming back, of marital rape exemptions in states' regulation of rape. See generally Jill Elaine Hasday, Contest and Consent: A Legal History of Marital Rape, 88 CAL. L. REV. 1373, 1392, 1484-85 (2000).

23. I thank Mary Becker for the point. For a full discussion, see Mary Becker, Family Law in the Secular State and Restrictions on Same-Sex Marriage: Two are Better than One, 2001 U. Ill. L. Rev. 1, 26 (1999).

24. 1930 Encyclical at $\mathbf{9} 53$.

25. 1968 Encyclical at $\mathbf{\Upsilon} 13$. 
woman's no, within canonical catholic thinking on the topic, apparently means no and must be abided, so long as the "no" rests on reasonable grounds, or at least, according to the Pope, so some men rightly think.

It is still, today, not entirely clear whether the "marital form" that sex must take, in order for it to be morally exemplary, includes a requirement that it be consensual. Thus, it is worth noting that in the quite detailed contemporary scholarly discussions of the multiple necessary conditions for moral sex penned by contemporary natural lawyers - that it be between married partners, that it be noncontracepted, that it be penetrative and penile-vaginal rather than oral or anal or digital, and so on-there is never a clear elucidation of the idea that it must also be consensual. There is no mention, for example, in Bradley and George's lengthy article from the mid-1990s in the Georgetown Law Journal detailing the nature of marital sex, that consent is a necessary condition for moral heterosexual relations. ${ }^{26}$ Of course, that may well be because Bradley, George, and other contemporary neo-natural lawyers now regard the necessity of consent as so apparent as to require no mention. But it's an odd and disconcerting omission nevertheless.

What, though, of unwanted marital sex? By that phrase, I do not mean rape, but rather, that marital sex to which a woman or a man unambiguously consents, but which she or he does not physically desire, and does not emotionally welcome or want. Does "sex of the marital form" that the natural lawyers laud include that sex? Is unwanted sex included, within the natural lawyers' blanket valorization of marital sex? Given the insistent and now millennialong valorization within Catholic theological thought of sex of the marital form itself-hetero, non-contracepted, vaginal-penile and penetrative - it is not unreasonable to surmise that an awful lot of that sex is indeed physically unpleasurable for women, simply because the type of sex endorsed has virtually nothing to do with the physical location of the sources of women's sexual pleasure. For that reason alone, it seems fair to speculate that much of the sex that the natural lawyers laud is also not physically desired by some, and maybe many wives. It might be fair to surmise, then, although there's remarkably little scholarship on the point,${ }^{27}$ that women in traditional marriages

26. George \& Bradley, supra note 11.

27. There is a growing body of social sciences scholarship on unwanted sex engaged in by college students and young adults of both sexes, some of it inspired by and informed by feminist concerns that the willingness of young women to consent to sex they do not want is a function of gender role stereotyping. See generally Alyson K. Spurgas, Embodied Invisible Labor and Sexual Carework: Women's Roles in Sexualized Social Reproduction within Intimate Relationships, (unpublished manuscript) 
engage in at least some marital sex (sex of the marital form) that they do not physically desire or find particularly pleasurable. If so, they are engaging in an act-unwanted, undesired, and unwelcome but nevertheless consensual sex-that is, according to a wave or recent social science research, apparently relatively common among heterosexual women, and, at least in some age groups among heterosexual men as well, and one that is increasingly recognized as carrying with it distinctive harms. ${ }^{28}$

Short of physical coercion, why might women, including married women in traditional marriages, engage in unwanted sex? To speculate: a married woman might engage in unwanted marital sex to retain her husband's affection, loyalty, fidelity, or support, to maintain relative domestic peace in the household, as a quid pro quo for her husband's day to day financial support for herself and her children, to avoid her husband's foul mood, wrath, anger, or violence, out of altruism, pity, or friendship, or simply because she feels it is

(on file with author); Emily A. Impett \& Letitia A. Peplau, Why Some Women Consent to Sex with a Dating Partner: Insights from Attachment Theory, 26 Psychol. of Women Q. 360, 366-67 (2002); Shantee Foster, Consensual Unwanted Sex: Motivations and Reservations (May 1, 2011) (unpublished Ph.D. dissertation, The University of North Carolina at Greensboro); Sarah J. Walker, When "No" Becomes "Yes": Why Girls and Women Consent to Unwanted Sex, 6 Applied \& Preventive Psychol. 157 (1997); Susan Sprecher et al., Token Resistance to Sexual Intercourse and Consent to Unwanted Sexual Intercourse: College Students' Dating Experience in Three Countries, 31 J. Sex ReSEARCH 125, 125 (1994); Lucia F. O'Sullivan \& Elizabeth R. Allgeier, Feigning Sexual Desire: Consenting to Unwanted Sexual Activity in Heterosexual Dating Relationships, 35 J. SEX RESEARCH 234, 241 (1998); Charlene L. Muehlenhard \& Stephen W. Cook, Men's Self-Reports of Unwanted Sexual Activity, 24 J. SEX RESEARCH 58 (1988); Miriam Lewin, Unwanted Intercourse: The Difficulty of Saying No, 9 PSYchology of Women Q. 184, 184-192 (1995); Pamela I. Erickson \& Andrea J. Rapkin, Unwanted Sexual Experiences Among Middle and High School Youth, 12 J. ADOLESCENT Health 319 (1991); Amy Buddie et al., Consenting to Unwanted Sex: Effects of Gender and Relationship Type, Address Presented at the Annual Meeting of the Southeastern Psychological Association (2011); There is only one article that I have found on the propensity of married women to consent to sex they don't want, and that involves young married brides in India. K.G. Santhya et al., Consent and Coercion: Examining Unwanted Sex Among Married Young Women in India, 32 InT'L FAm. Planning PersP. 124, 124 (2007).

28. Robin West, Sex, Law, and Consent, in The Ethics of Consent: Theory AND Practice 221, 243 (Franklin Miller \& Alan Wertheimer, eds., 2010) [hereinafter West, Sex, Law, and Consent]; see also Robin West, The Harms of Consensual Sex, in The Philosophy of SEX: Contemporary Readings 317, 319 (Alan Soble \& Nicholas Power, eds., 5th ed. 2008). 
expected of her by their social or religious community. Natural lawyers might find these "instrumental" uses of the sexual body to achieve other ends worrisome, and I think they would be right to do so. In an arguably prescient passage, Pope Pius argued that the use of birth control within marriage might encourage in men a tendency to view their wives and their wives' bodies as a vehicle for the satisfaction of their own physical desires, rather than with the reverence that God and the Church demand and which their wives deserve. ${ }^{29}$ This is at least an indirect but notably feminist condemnation of not only a husband's exploitation of his wife's body, but also and more generally a critique of unwanted marital sex, although couched within an argument against birth control and sex engaged in for pleasure, not in an argument focused on harms to the woman whose body may come to be so regarded.

The natural lawyers' reason for finding instrumental, unwanted, marital sex to be worrisome, however, is clearly its instrumentality and not its "unwanted-ness." That is, neo-natural lawyers might well object to unwanted marital sex engaged in for the purpose of securing domestic peace, or for financial support, or to meet community expectations, or to satiate a husband's physical sexual needs. However, they would object to all that unwanted marital sex (assuming they would) for precisely the same reason that they object to contracepted sex-for-pleasure or sex-for-money or sex-for-love: the instrumental use of the sexual body for ends other than what gives sex its moral meaning, which is the conjugal union of a man and a woman in a sexual act of the reproductive form. There is, in other words, in the natural lawyers' account, a blanket condemnation of "instrumental" sex, and presumably that would include unwanted instrumental sex as well. What there isn't, though, in either academic natural law writing, nor in any of the Encyclicals (that I can find), is a blanket condemnation, or really any criticism at all, of unwanted sex "of the marital form" whether instrumental or not. And of course there is no discussion or recognition of the harms that unwanted sex might cause. ${ }^{30}$

29. See 1930 Encyclical; 1951 Encyclical; 1968 Encyclical.

30. In fact, in a striking passage, Bradley and George argue very much to the contrary - that unpleasurable sex that is not instrumental, is not, therefore, wrong, and might even be morally required. Even infertile married couples who can't procreate and don't get any pleasure from sex nevertheless have a "reason" - meaning, a moral reason, rather than an instrumental reason, and thus, presumably, a duty - to engage in marital sex, regardless of both their infertility and their mutual lack of desire. While they don't say so explicitly, what this seems to suggest is that a wife has a moral duty to engage in sex which her husband may very much desire but which she does not desire, and which he might 
Does all of this unwanted sex cause harm? I have argued elsewhere, as have a handful of feminist legal theorists and more recently a number of social scientists as well, that unwanted sex-sex to which women consent but which they do not desire-carries with it a host of possible psychic and emotional and political harms. I will elaborate on those harms in the next section. My point here is narrower: the natural lawyers' valorization of marital sex, on which their condemnation of birth control rests, seemingly endorses as morally salutary and perhaps even morally obligatory precisely this unwanted sex, so long as it is of the marital form. Again, that unwanted sex might be injurious and if so, then it might well be all the more injurious when inside long term relationships such as traditional marriage than outside it. Here, I just want to make clear that the natural lawyer's conception of heterosexual morality is not just inattentive to those possible harms. It seemingly celebrates the sex that causes them.

There is, though, a third and much less contestable harm that is quite clearly occasioned by "sex of the marital form," and that is, oddly, almost entirely untouched by the neo-natural lawyers' contemporary critics. The natural lawyer's valorization of procreative marital sex includes all marital sex, not only whether or not it's wanted and perhaps whether or not it's consensual, but also whether or not it leads to unwanted pregnancies. Marital sex, recall, at least for the modern popes, might be permissibly regulated through natural forms of birth control - meaning rhythm methods - but it must also always be open to at least the possibility of conception. And, some of those pregnancies - some sizeable subset of all the pregnancies that result from the marital sex that is valorized by natural lawyersmight not be in the woman or her husband or her other children's best interests, all things considered. Some of those pregnancies, whether or not wanted, might be a burden to the woman's health or wellbeing, or to her education, her employment, or her employment prospects, or to the couple's pocketbook. Those pregnancies might be objectively harmful, or at least costly, for any of those reasons. In addition, though, many of the pregnancies caused by marital sex are clearly not wanted or desired by the women who will bear them, as evidenced in part by the abortion rate for women in traditional as well as non-traditional marriages or relationships. ${ }^{31}$ Yet, according to

enjoy but from which she receives no pleasure. See generally George \& Bradley, supra note 11, at 305-306.

31. See Fact Sheet: Unintended Pregnancies in the United States, GutTmacher Inst. (July 2015) [hereinafter GutTmacher], http://www.guttmacher.org/pubs/FB-Unintended-Pregnancy-US.html ("Some groups - including higher-income women, white women, college graduates and married women - are comparatively successful in timing 
the neo-natural lawyers, all marital sex-not only those sexual acts which lead to wanted pregnancies, but also those which lead to unwanted pregnancies - constitute an unassailable, natural, human good.

In contrast to the popes' and the neo-natural lawyers' possibly shifting position on the morality of nonconsensual or unwanted marital sex, their position on this point is absolutely unambiguous and distressingly unchanging. The 1930, 1951, and 1968 Encyclicals are all quite clear on this point, as are the neo-natural lawyers' more contemporary elucidation of the position from the 1990s and 2000s. ${ }^{32}$ A pregnancy that is unwanted nevertheless ushers in a new life that must be welcomed, nurtured and celebrated. A desire to not become pregnant, even if both parties share it and even if it is entirely "reasonable," and even if it is therefore sufficient to justify abstention, is not a sufficient warrant for the use of artificial birth control that will actually prove effective. To put this all together, a married woman, according to both popes who have spoken in detail on the subject, has a moral obligation to have procreative marital sex she does not desire and from which she receives no pleasure, and then a further obligation to bear a pregnancy she does not desire, and which may threaten her life, her health, her pocketbook, or her family's overall wellbeing. Because they do not address it, it is not at all clear whether contemporary natural law scholars, including Finnis, Bradley, and George, would disagree.

What harms attend all of those unwanted pregnancies? All pregnancies, certainly including intensely wanted ones, carry risks and costs to both a woman's health and to her mobility and employment. ${ }^{33}$ Unwanted pregnancies, however, carry far more. Some of these risks and costs are well known. First, a lack of desire to be pregnant is surely oftentimes a sensible proxy for greater harms down the road: If a woman did not want the pregnancy because of health risks, those risks are obviously more likely to come to pass; unwanted pregnancies will tend to correlate with those pregnancies that are more health endangering and life threatening than intended

and spacing their pregnancies. For example, higher -income white women experience unintended pregnancy at less than half the national rate (20 vs. 54 per 1,000)."). See generally Lawrence B. Finer \& Mia R. Zolna, Shifts in Intended and Unintended Pregnancies in the United States, 2001-2008, 104 AM. J. Pub. Health 43, 45 (Supp. 2014).

32. See 1930 Encyclical; 1951 Encyclical; 1968 Encyclical; George \& Bradley, supra note 11, at 305; Grisez, supra note 11, at 365.

33. See generally Eileen McDonagh, Breaking the Abortion Deadlock: From Choice to Consent (1996); Shari Motro, Preglimony, 63 Stan. L. REV. 647 (2011). 
and wanted pregnancies. ${ }^{34} \quad$ Likewise, if she did not want the pregnancy because of worries about employment, then it is more likely than if the pregnancy were wanted, it may well cause an interruption in her work. ${ }^{35}$ If she did not want the pregnancy because she has too many children to care for already, then, again, it is likely that she was right to so worry: her mothering and her existing children may suffer. So will her engagement in educational, social, civic and cultural life. A lack of desire to be pregnant, in other words, is clearly a proxy for the familiar objective harms of pregnancy. And of course, a married woman's lack of desire for a pregnancy means that it may lead either to an abortion, in spite of whatever strong moral objections she may harbor to the procedure, or to an unwanted birth. Either outcome is harmful in well documented ways. ${ }^{36}$ A woman's lack of desire for a pregnancy, in other words, is a pretty good indicator that the pregnancy may be against her or her family's interest.

But an unwanted pregnancy might also carry less sizeable but less noted risks of psychic, emotional and political harms - harms which are independent of or in addition to the increased risks of whatever factors might have rendered the pregnancy unwanted. Of course, an undesired pregnancy is obviously less joyful than a wanted pregnancy, and without that joy, the discomfort and sickness attendant to even much wanted pregnancies are significant psychic as well as physical harms. But there are other harms as well, less noticed, but equally important, that attach to an unwanted pregnancy, even if that pregnancy is medically unexceptional, and whether or not it leads to a live birth, miscarriage or abortion. I believe there are four harms

34. See GutTMACHER, supra note 31 (noting that "[b]irths resulting from unintended or closely spaced pregnancies are associated with adverse maternal and child health outcomes, such as delayed prenatal care, premature birth and negative physical and mental health effects for children.")

35. Id. ("The costs associated with unintended pregnancy would be even higher if not for continued federal and state investments in family planning services. In 2010, the nationwide public investment in family planning services resulted in $\$ 13.6$ billion in net savings from helping women avoid unintended pregnancies and a range of other negative reproductive health outcomes, such as HIV and other STIs, cervical cancer and infertility. In the absence of the current U.S. publicly funded family planning effort, the public costs of unintended pregnancies in 2010 might have been $75 \%$ higher. Total public expenditures on unintended pregnancies nationwide were estimated to be $\$ 21.0$ billion in 2010. Of that, $\$ 14.6$ billion were federal expenditures and $\$ 6.4$ billion were state expenditures.")

36. See id. There are no uncontested long lasting harms of legal and safe abortions, but with the increasing number of legal restrictions on the availability of abortion, it is no longer safe to assume that abortions are either legal or safe. 
worth noting, gleaned from feminist commentary and autobiographical sources. First, and with or without morning sickness, an unwanted pregnancy compromises a woman's bodily integrity. Her body is no longer the border between herself and the outside world, she has become in effect permeable. ${ }^{37}$ Second, and as a number of philosophers have argued in the different context of abortion rights - and somewhat analogously to the effect of a military draft on men's bodies - an unwanted pregnancy undermines a woman's self-sovereignty. It reorients the purpose of her body, both in her own perception, and that of others: her body is no longer a vehicle for the sustenance and nurturance of the woman's self. Her body becomes the vehicle for the sustenance, nurturance, and facilitation of somebody else. ${ }^{38}$ Third, as a number of legal scholars as well as philosophers have argued, an unwanted pregnancy robs the pregnant woman of some measure of autonomy - it limits her freedom of movement and her range of choices and options, sometimes quite severely, which, again, is obviously a harm. ${ }^{39}$ Lastly, an unwanted pregnancy is quite literally alienating, in a traditionally Marxist or labor-oriented sense: her future labor (including both the labor of the birth itself and her future maternity) as well as her present body must be dedicated, not to her own ends, but to the health of the fetus and then the well-being of the child. ${ }^{40}$ The relatively unstudied psychic (and political) harms of unwanted pregnancy, then, entirely aside from the familiar litany of financial and physical costs, are at least fourfold: an unwanted pregnancy compromises a woman's physical integrity and her self sovereignty, and it limits her autonomy and her destiny in ways which ought to be easily recognized, at least by legal and labor scholars, as peculiarly but profoundly alienating.

37. This point is emphasized in the "Voices Brief" filed in Brief of SeventySeven Organizations Committed to Women's Equality as Amici Curiae in Support of Appellees at 2-3, Webster v. Reproductive Health Services, 492 U.S. 490 (1989) (No. 66-605) 1989 EL 1127689, at *1-2 [hereinafter "Voices Brief"].

38. This is portrayed vividly in Judith Thompson's famous metaphor for an unwanted and nonconsensual pregnancy, of a woman being forcible tied to a born person, who will perish without the woman's relinquishment of the use of her body for the purpose of his sustenance. See Judith Jarvis Thompson, A Defense of Abortion, 1 J. PhIL. \& PuB. AfF. 47, 57 (1971).

39. Voices Brief, supra note 37; Andrew Koppelman, Originalism, Abortion, and the Thirteenth Amendment, 112 CoLuM. L. REV. 1917, 1936 (2012).

40. This is the focus of the justly famous article by Andrew Koppelman on unwanted pregnancy as slavery, see Koppelman, supra note 39. See also Jed Rubenfeld, The Right of Privacy, 102 HARV. L. REv. 737, 739-40 (1989). 
Why has this prong of the natural lawyers' brief - that marital sex that leads to unwanted pregnancies is an unalloyed intrinsic, human, natural, good - not attracted a more vigorous response from the neo-natural lawyers' contemporary critics? One reason may simply be because of a widespread belief that today the argument lacks practical significance: the natural lawyers have just flat-out lost this argument, critics might think, in the court of public opinion, which is really the only court that matters, or so we are told. Catholic women, after all, use birth control in the same large numbers as non-Catholic women and do so in open defiance of the Catholic leadership's counsel. Women with unwanted pregnancies, both in and outside of marriage, and again both Catholic and non-Catholic, also terminate those unwanted pregnancies that occur in spite of the use of birth control through abortions in large numbers. The availability of abortion and the widespread use of birth control may render the harms occasioned by unwanted pregnancies seemingly trivial, and therefore marginal - something that perhaps once was a problem but simply is no longer.

There may, though, be less obvious reasons for the reticence of the natural lawyers' modern critics to address these harms, entirely aside from the belief, which I think is misguided, that the argument is just too discredited to matter. First, many would-be critics on all sides of this debate, I suspect, tend to regard pregnancies that result from sex in which the parties knowingly fail to use birth control, and thus knowingly assume the risk of the unwanted pregnancy that may result, as an "intentional" or at least quasi-intentional pregnancy: the pregnancy is the result of an act in which parties engaged, knowingly accepting the risk of its probably consequences. This seems clearly true, for example, of women in traditional marriages who are morally opposed to the use of artificial birth control and try, but fail, to control their fertility solely through rhythm methods: if such a woman becomes pregnant, the critic might reason, she's laid her bed so now she must lie in it. Her problems, or injuries, are not of concern, from a liberal perspective. The same might be thought of women, whether married or not, who don't wish to become pregnant, and know full well how birth control works, and certainly have no moral objection to it, but carelessly or recklessly fail to use it. Both groups of women in some sense have knowingly assumed a risk of pregnancy. For both groups, the unwanted pregnancy that results can fairly be regarded as "consensual." ${ }^{41}$ And, for a host of reasons I've discussed elsewhere, ${ }^{42}$

41. For an argument that they are better understood as nonconsensual, see MCDONAGH, supra note 33, at 60-64.

42. See generally Robin West, Authority Autonomy and Choice: The Role of Consent in the Moral and Political Visions of Franz Kafka and Richard Posner, 99 HARv. L. REv. 384 (1985); Robin West, Submission, Choice, 
we may be inclined to assume that all such consensual albeit unwanted pregnancies - pregnancies in which the risk of conception was consciously assumed-like all consensual acts, can't really cause harm to those who intended them, anymore than the purchaser of a lottery ticket can be said to have been harmed by his payment of the purchase price, when the lottery ticket turns out not to be a winner. ${ }^{43}$ To assume otherwise would be unduly paternalistic: the woman had herself assessed the risk of the pregnancy and had the sex anyway, so she must have herself calculated that the risk of the pregnancy times the cost was simply outweighed by the value of the sex that might cause it. Who are we to second-guess her? If so, then while the unwanted pregnancy may impose a cost, it can hardly be said to impose a harm: it is a cost for which she was fully compensated by the pleasure of the sex that brought it about. Thus, the harms of unwanted pregnancies simply disappear behind the veil of the apparently consensual assumption of their risk.

More generally, though, we may fail to see that intentional and fully consensual acts can impose harms because we don't fully understand that we often intend to bring about states of affairs we don't ourselves want, and we all may particularly fail to see thiseven semi-consciously refuse to see this-with respect to women's intentional use of their bodies. As a consequence, we may fully understand that truly unintentional pregnancies - such as pregnancies where birth control is used but fails, or pregnancies that follow a rape, or pregnancies that occur where birth control is unavailable, or where the parties suffer a profound ignorance regarding its necessityimpose cognizable harms. What we may not well understand, by contrast, is that consensual (or intentional) but nevertheless unwanted pregnancies, where the risk of an unwanted pregnancy is at least dimly but nevertheless consciously assumed, either in or outside marriage, and whether that risk is consciously assumed either because of duty, or because of moral objections to birth control, or by virtue of pressure from a partner, or from peer pressure, also carry with them grave harms. One reason we might not see this is that we have yet to understand that such a category might exist, in which we sometimes intend to bring about states of affairs that might harm us. And, I think we may have a particular blind spot when faced with

and Ethics: A Rejoinder to Judge Posner, 99 HARV. L. REV. 1449 (1986); West, Sex, Law, and Consent, supra note 28.

43. The example is taken from Richard A. Posner, The Ethical and Political Basis of the Efficiency Norm in Common Law Adjudication, 8 HoFsTRA L. REV. 487, 492 (1980), and is criticized in Robin West, Authority Autonomy and Choice: The Role of Consent in the Moral and Political Visions of Franz Kafka and Richard Posner, 99 HARV. L. REV. 384, 405 (1985). 
the possibility that women may do this frequently, and may do so, in fact, very frequently with respect to our bodies: "our bodies" that, fifty years after that the publication of that book with that hopeful and buoyant title, we still don't quite see as "our selves."

Why might that be the case? Least charitably, the psychic or emotional harms occasioned by intentional but unwanted pregnancies may elude notice simply because the use of women's bodies for reproductive or sexual ends that are disjoined from women's own desires strikes us all, and not just natural lawyers, as an acceptable distribution of societal resources, or as central to a laudable understanding of femininity, or both, at least so long as the pregnancy can somehow be characterized as at least nominally intentional. A woman who sacrifices her own interests, career, pleasures, self sovereignty, autonomy, and integrity for a pregnancy she does not want is, after all, simply engaging in a distinctive form of altruism-an altruism that might well be distinctively unchosen (even if the risk of it was consensually assumed) and hence distinctively illiberal, as well as distinctively female. ${ }^{44}$ A woman who bears an unwanted but consensual pregnancy has not decided to share her body with that of another and then taken actions that will allow her to do so, as we might at the end of the year decide to share our income with others in need, and then write the checks that enable us to do so. She has, rather, assumed a risk that something she does not want-a pregnancy - might follow from an act she may engage in - sex. The result - the pregnancy - forces her into an altruistic sharing of her body's resources. Again, women who do this routinely and as a matter of self-identity or self-definition, are thus engaging in a form of altruism that is both distinctively female and distinctively illiberal. That is just not a coincidental pairing. The identification of female (rather than male) altruism with unchosen and sometimes forced sharing, rather than with chosen giving, is a deep one. For a very long period in human history, in fact, that distinctive mode of ethics - forced altruism, particularly forced altruism regarding the body's resources - has been a large part of what has defined not just femininity, but also, and more specifically, the deep incompatibility of femininity with liberal ways of being in the world.

And, that forced sharing - that feminine, unchosen, physical altruism - is right at the heart of the natural lawyers' conception of femininity, of family, and ultimately of their opposition to birth control. Thus, female sacrifice (up to and definitely including the sacrifice of life itself) is explicitly and emphatically praised in the 1930

44. See, e.g., Larry Blum et al., Altruism and Women's Oppression, in Women and Philosophy 222, 224-30 (Carol Gould \& Marx Wartofsy eds., 1976). 
encyclical-a woman who passively sacrifices her health and perhaps her life for the sake of an unwanted pregnancy is to be much admired, but certainly not pitied - she will, after all, receive her reward for her sacrifice in heaven - while the woman who willfully seeks to avoid a pregnancy or end one because of health or life is to be condemned as having committed a grave $\sin .^{45}$ Continuing through to today, this particular form of forced altruism, again explicitly for the natural lawyers but likely in some form implicitly for many of the rest of us as well, is simply part of what it means to be a wife. A wife just is someone who engages in physical altruism, and who does so by virtue of status rather than consent. But whether or not that's a matter of common understanding, this understanding of what it means to be a "wife" is quite explicit in the encyclicals, ${ }^{46}$ and it might be implicit in the neo-natural lawyers' failure to recognize the harms of unwanted pregnancy as harms at all, and thus to temper or condition their valorization of marital sex. The same set of assumptions, however, might also haunt, and limit, the critical literature on the neo natural lawyers' conception of heterosexual morality.

Whatever the reason for it, though, the lack of attention of both the natural lawyers and their critics to the harms caused by all of those unwanted pregnancies that are themselves caused by marital sex-meaning, again, procreative, uncontracepted sex of the marital form - is unfortunate. As we move into a world in which some women but not others have access to birth control, greater understanding of its point and knowledge of its effectiveness, and greater choice among its forms, we will thereby be moving into a world not only of unequal sexual freedom, but also of unequal control of fertility. In such a world, more women will have unwanted pregnancies, whether intended or not. And, perhaps it needs saying although it shouldn't, most of those women who will bear those unwanted pregnancies will be poor. ${ }^{47}$ This is a harm with which we should reckon.

To sum this up: as is now fairly widely acknowledged, marriage is not a necessary condition for the morality of any and all pregnancies that may result from sex. This part of the natural lawyer's conception of sex has been widely criticized, and our law, our politics, and our legal attitudes all reflect that rejection. We no longer stigmatize illegitimacy, or sequester our pregnant and unmarried daughters, or emblazon scarlet letters on unmarried pregnant women's dresses or foreheads. We celebrate the in vitro or surrogacy

\section{See 1930 Encyclical at 9 58, 64 .}

46. See, e.g., 1930 Encyclical at 9 26-29, 72-75.

47. See Fact Sheet: Unintended Pregnancies in the United States, GutTmacher Inst. (Feb. 2015) (noting that unintended pregnancy rates are highest among poor and low-income women). 
pregnancies sought and treasured by our straight and gay friends, partners, and ourselves. What has not been so widely criticized, because it is so rarely discussed, is the natural lawyer's valorizing claim that marriage is also a sufficient condition, not only for the morality of the unwanted sex that takes place within it, but also for the unwanted pregnancies that are its natural and completely foreseeable result. But this claim too is wrong and even clearly wrong. It is surely wrong to valorize nonconsensual sex-meaning rape - within marriage, and I will argue below that it is wrong as well to valorize unwanted sex, both marital and non-marital. But it is also wrong to valorize the marital sex, whether wanted or unwanted, that may lead to unwanted pregnancies. Whether inside or outside marriage, a wanted pregnancy is more joyous, less harmful, less costly and more emotionally and spiritually uplifting than an unwanted pregnancy. The ideal conditions for a pregnancy are straightforward enough and widely understood: a pregnancy should be supported by loving parents-to-be, the pregnant woman should be in good health, there should be ample and planned provision for the child's nutrition, housing and schooling, and there should be substantial time in both parents' lives to devote to the work of child-raising. But as a moral minimum, a pregnancy, like sex, should be wanted. It should be desired. It should be celebrated by the woman herself and welcomed by her partner. The natural lawyers' celebration of the morality of all marital sex, including the marital sex that causes unwanted pregnancies, fails to recognize this moral minimum.

\section{The SexuAl-Libertarian Brief For Birth Control}

The libertarian brief for the use and dispensation of birth control, like the natural lawyers' argument against it, also rests on a particular conception of heterosexual morality. All sex, according to the sexual libertarian, including all heterosexual sex, is an intrinsic human good, and a good to which all individuals are entitled, so long as the sexual transactions that facilitate it are fully consensual acts, and are therefore conducive to, as well as a product of, individual autonomy. The formal parallelism of this conception with the natural lawyer's conception is striking. The sexual libertarian, like the natural lawyer, believes that sex is intrinsically good so long as it is (x), but while for the natural lawyer, that $(\mathrm{x})$ is marriage, for the sexual libertarian, that $(\mathrm{x})$-the condition for the morality of sex-is consent, or, broadly, autonomy. For the natural lawyer, sex must be of the reproductive form - and therefore marital - to be moral, and for the sexual libertarian, sex must be consensual-and therefore conducive to autonomy - to be moral. And, as was true of the natural lawyer's, the libertarian's conception of sexual morality quite cleanly breaks down into both a censorial and a valorizing claim, and again, as was true of the natural lawyer's, both the censorial and the 
valorizing claim are foundational to their argument regarding the use of birth control.

The sexual libertarian's censorial claim is this: Sex that is not consensual is immoral, because it interferes with human autonomy, just as is nonmarital sex, to the natural lawyer, including contracepted sex within marriage, because of its interference with the fusion of body and spirit necessary to the actualization of the moral good of marriage. Again it's worth noting the parallelism: for the natural lawyer, sex that is not marital is therefore immoral, for the libertarian, sex that is not consensual is what we should condemn. The sexual libertarian's valorizing claim is just this: Sex that is consensual is not only not immoral, it is an intrinsic human good. ${ }^{48}$ Consensual or autonomous sex (hereinafter, "autonomous sex,") should then be celebrated, not just permitted, and in all its forms and varieties. Its moral value is not dependent upon any further conditions. It clearly doesn't have to be procreative, either in form or fact; it doesn't have to be open to the blossoming of a new life; it doesn't, therefore, have to be non-contracepted. It doesn't have to be heterosexual, missionary, penile-vaginal or penetrative. It doesn't have to be reproductive, marital, or emotive. It doesn't have to have any particular form, or motive, or end. It doesn't have to be within a committed long-term relationship, or any relationship, and it certainly doesn't have to be within marriage. It can also be, although it doesn't have to be, instrumental toward some end other than the pleasurable or reproductive consequence of the sex itself: it can be enjoyed or traded for money, for security, for friendship, or for love, no less than for pleasure.

Sex is not, though, simply a commodity, the trade of which is conducive to wealth. Rather, within the libertarian conception, autonomous sex is also a source of meaning, of expression, and of individual identity. ${ }^{49}$ It is a part of the inalienable liberty to which we are entitled as a matter of birthright. In short, we have a human right to it, and at least post-Eisenstadt and all the more emphatically since Lawrence, we seem to have a constitutional right to it as well. ${ }^{50}$

48. See generally David Richards, Sex, Drugs, Death And the Law: An ESSAY ON HUMAN RightS AND OVERCRIMINALIZATION (1986).

49. Id. at 41 ("Such activity is clearly a natural expression of human sexual competences and sensitivities... To deny the acceptability of such acts is itself a human evil, a denial of the distinctive human capacities for loving and sensual experience without ulterior procreative motives-in a plausible sense, itself unnatural"); GARROW, supra note 4. But see Thomas C. Grey, Do We Have an Unwritten Constitution?, 27 Stan. L. REV. 703 (1975).

50. See Randy E. Barnett, Justice Kennedy's Libertarian Revolution: Lawrence v. Texas, 2002-2003 Cato Sup. Ct. Rev. 21, 2141. For a critical reading of the sexual libertarianism explicit in 
So long as it is consensual, sex, according to the valorizing prong of the liberal conception, whether or not it is hetero, missionary, or vaginal-penetrative in form, and whether or not it is for pay, for pleasure, for reproduction, or otherwise, is a great human good. Consensual sex is of positive human value, at least to the participants and possibly to the rest of us as well.

How do these claims jointly ground the libertarian brief for birth control? The right to use birth control, free of the constraining and condemning arm of the state - the right essentially created in Griswold and Eisenstadt - follows directly from a combination of traditionally liberal or Millian arguments regarding the moral limits on state power over acts that impose no harms on third persons, with the content - and limits - of the sexual libertarian's censorial claim. Heterosexual sex is wrong, according to the sexual libertarian, if it is nonconsensual, but only if it is nonconsensual: if it is nonconsensual, it is assaultive, and like all assaults by definition imposes harms. ${ }^{51}$ Therefore, consensual (and therefore non-assaultive) but nonprocreative and hence contracepted sex, no less than consensual and therefore non-assaultive but procreative sex, or sex for pleasure, or sex for love, or sex for companionship, or sex for money, is just not in the category of the kinds or forms of sex, or any other kinds of victimless acts, which we should censor or condemn. The use of birth control is not an affirmative moral wrong. There's no sensible moral argument against its use. Eisenstadt, of course, constitutionalized a part of this claim, albeit obliquely. ${ }^{52}$ If constitutional privacy protects anything at all, it should protect the use of birth control: it is a paradigmatic instance of self-regarding behavior that is both central to identity and inflicts no harms on others.

The argument for the accessibility and dispensation of birth control, however - rather than just for its decriminalizationobviously doesn't follow from the libertarian's censorial claim alone; that the use of contraception is not a moral wrong, and should not be a legal wrong, might imply that we should not criminalize it and should perhaps constitutionalize a right to it, but it obviously doesn't

Lawrence, see Marc Spindelman, Surviving Lawrence v. Texas, 102 Mich. L. REV. 1615, 1629 (2004) for a discussion of how the Court vindicates sexual liberty by recognizing heterosexuals' sexual rights and extending that liberty to lesbians and gay men, sometimes to the detriment of safety.

51. For a general discussion, see West, Sex, Law, and Consent, supra note 28 , at 222 .

52. For an argument that although this was how the decision was widely read, that this was likely not what the Court intended, see Thomas C. Grey, Eros, Civilization and the Burger Court, 43 LAW \& ConTEMP. PROBS. 83, 88-89 (1980). 
follow that birth control is such a good thing that it should be made broadly available. The argument for the dispensation of birth control (rather than just its legality), however, does follow, and quite directly, from the libertarian's valorizing claim regarding the high positive value of autonomous sex. Because autonomous sex is an intrinsic human good, anything that liberates autonomous sex is of value, and anything that confines it, is a cost. Pregnancy and the fear of pregnancy obviously greatly inhibit heterosexual sex and sexual expression. Birth control frees us from those fears and consequences, and thus frees heterosexual women and men both for the autonomous sex, sexual expression and sexual pleasure to which we are all entitled. ${ }^{53}$ Birth control, in short, is facilitative of sexual liberty. ${ }^{54}$ Therefore, birth control is not only not a wrong, but it is of great instrumental utility - it facilitates the enjoyment of a basic human good..$^{55}$ If so, then we seemingly have not only a constitutional right to its use, but at least a moral right as well to its dispensation.

Over the last half-century, the sexual libertarian's valorizing claim regarding autonomous sex-by which I mean their embrace of autonomous sexuality as an intrinsic human good-has either implicitly or explicitly informed a number of pro-sex, liberalizing legal reforms, beginning with, but then moving well beyond the birth control movement itself. ${ }^{56}$ It has, most recently, been at the heart (although not always explicitly so) of the various legal and political movements that have challenged moralistic censure of gay and lesbian sex: if consensual sex is an intrinsic good, then consensual gay sex is

53. Thus, David Richards argued in the aftermath of Eisenstadt that birth control is of such high value in large part because it frees women to enjoy sex, without fear of pregnancy, and perhaps for the first time in history. DAvid A.J. Richards, TOleration AND THE CONSTITUTION 259 (1986).

54. GARROW, supra note 4.

55. David Richard makes this argument directly, albeit briefly, in David A.J. Richards, Toleration And the Constitution 259-60 (1986).

56. David Richards for example discusses birth control, and its instrumental value for the enjoyment of autonomous sex, only very briefly, in DAVID A.J. Richards, Toleration And the Constitution 259 (1986). He doesn't even mention much less discuss or take seriously the possibly deleterious effects of that argument. Other sexual libertarians give it shorter treatments or none at all. David Garrow's legal history of birth control, tellingly titled SEXUALITY AND LIBERTY, is a meticulous history of the sexual libertarian case for birth control. Again, he does not provide any discussion at all of the claim's limitations, nor does he discuss the critical views of others, other than those of conservative sexual moralists opposed to birth control. 
as well. ${ }^{57}$ It has likewise motivated and informed the liberal feminist campaign ${ }^{58}$ against the various antipornography ordinances that were drafted by radical feminists in the nineteen eighties, and that were aimed at providing women a private cause of action against pornographers. ${ }^{59}$ If the sex depicted in pornography is consensual on all sides, according to liberal feminist anti-censorship theorists and activists, then not only does it do no harm, but it is also serves (and is) an intrinsic good: sexual expression, like sex itself, is conducive to full and rich lives for women as well as for men, unlike the censorial impulse that seeks to repress it, and pornography, so long as it is consensual, facilitates that expression. ${ }^{60}$ The same commitment has likewise been at the core of a number of self-labelled "pro-sexfeminist" legal arguments of the eighties and nineties, including critiques of the "hostile environment" prong of sexual harassment ${ } \mathrm{law}^{61}$ and of perceived excesses in the reach of feminist reforms of rape law, both of which, according to pro-sex feminists, endanger the free expression of sexuality. ${ }^{62}$ Likewise, it is the foundation for queer theorists' internal challenges to the liberal campaign for same sex marriage: that campaign is obviously committed to a domesticated and assimilated form of gay sexuality that willingly embraces explicitly conservative constraints on sexual expression outside of marriage. ${ }^{63}$ At the more extreme margin, the valorizing claim has been at the center of queer critiques of the safe sex campaigns

57. David A. J. Richards, Women, Gays, And the Constitution 245-52 (1998); Richards, supra note 48, at 270-71; Feldblum, supra note 14; Macedo, supra note 14, at 282.

58. See Nan D. Hunter \& Sylvia A. Law, Brief Amici Curiae of Feminist Anti-Censorship Taskforce, Et Al., in American Booksellers Association v. Hudnut, 21 U. Mich. J.L. Reform 69, 69 (1987).

59. See generally Catharine A. MacKinnon, Only Words (1993); Catharine A. MacKinnon, Toward a Feminist Theory of the State (1989).

60. See Hunter \& Law, supra note 58, at 70, 121; Robin West, The Feminist-Conservative Anti-Pornography Alliance and the 1986 Attorney General's Commission on Pornography Report, 12 AM. B. FOUND. RES. J. 681, 682-684 (1987).

61. Vicki Schultz, Reconceptualizing Sexual Harassment, 107 YALE L.J. 1683 (1998); KATHERINE M. FRANKE, What's Wrong with Sexual Harassment?, 49 STAN. L. REV. 691, 711 (1997).

62. Jed Rubenfeld, Rape-by-Deception-A Response, 123 YALE L.J. ONLINE 389, 392 (2013).

63. Michael Warner, The Trouble with Normal 90-91 (The Free Press 1999). 
encouraging the use of condoms among gay men. ${ }^{64}$ Again, the logic of all of these pro-sex movements rests on the valorizing prong of the liberal conception of sex: Autonomous sex is an intrinsic human good. Consent may or may not be a necessary condition for moral sex; on that, sexual libertarians and queer theorists sometimes split. ${ }^{65}$ But it is clearly a sufficient condition for the morality of sexual acts. On that, they all agree. Autonomous sex is very, very good, including autonomous heterosexual sex. And, because it is so good, birth control, which liberates it, is of high instrumental value. Autonomous sex is a human good, and therefore contracepted heterosexual sex is likewise, simply because birth control provides the means by which heterosexual sex can be all the more unconstrained.

Now, unlike the censorial claim, neither the libertarian valorization of autonomous, non-procreative heterosexual sex nor the argument for the utility of birth control that it implies has been subjected to much criticism, or even much discussion, within liberalism itself; in fact, there's virtually none. The parallel with the neo-natural lawyer's conception of heterosexual morality is striking: just as the harms caused by marital sex have been unnoticed or unreckoned by neo-natural lawyers, so the harms caused by autonomous heterosexuality have largely been unnoticed or unreckoned by sexual libertarians. Liberals, sexual libertarians, queer theorists, and pro-sex feminists have argued instead, and incessantly, over the meaning and limits and implications for law of the libertarian's censorial claim: what "counts" as consent, what might be the markers of non-consent, and whether non-consent is or isn't sufficient to render sex criminal. Does yes mean yes, and does no mean no? ${ }^{96}$ What is and what should be the consequence of mistakenly interpreting a "no" as a "yes"? Does deceit, like force, sufficiently vitiate consent so as to render the sex to which it may lead a crime? ${ }^{67}$ They have looked minutely, to borrow Alan Wertheimer's phrase, at the "morally transformative" function of consent in the criminal law and in positive morality both: the way in which consent, and the permission it conveys, transforms what would otherwise be immoral and possibly illegal assaultive

64. For discussion, see generally Marc Spindelman, Sexual Freedom's Shadows, 23 YALE J.L. \& Feminism 179, 181 (2011).

65. See, e.g., Sarah Beresford, The Age of Consent and the Ending of Queer Theory, LAWs 760, 763-70 (2014).

66. Jed Rubenfeld, Mishandling Rape, The New York Times Sunday REviEw (Nov. 15, 2014), http://www.nytimes.com/2014/11/16/opinion/ sunday/mishandling-rape.html?_r $=0$.

67. Rubenfeld, supra note 62, at 396. 
behavior into something that is at least permitted. ${ }^{68}$ They have examined, criticized, torn apart, dissected, deconstructed and reconstructed the censorial claim, in other words, near obsessively. ${ }^{69}$

Given the elaborate care with which sexual libertarians have examined the censorial claim, it is all the more striking that they haven't looked nearly so closely, and almost never critically, at the sex they valorize. And because of that, they have not looked at the harms that might be intensified by their particular argument for the instrumental utility of birth control. What does the liberal's blanket approval of autonomous, non-procreative heterosexual sex (hereinafter, autonomous sex), in all its guises, cover? What harms does it legitimate? The next section attempts a broad outline of what those harms might be, and concludes with suggestions of how to minimize them, including an examination and reconstruction of the libertarian's brief for birth control.

\section{Is Autonomous Sex an Intrinsic Good? One Critique}

Heterosexual sex that is unambiguously consensual -in short, "autonomous sex" - may nevertheless be harmful. A few of those harms are recognized, and much discussed, by liberals and conservatives both: autonomous sex can, after all, cause both sexually transmitted disease and, if birth control fails or is misused, unhealthy as well as unwanted and unwise pregnancies. Because of both, it can sometimes have quite disastrous consequences; it can alter the course of a life, or end one. Liberals and libertarians who valorize autonomous sex of course realize this, and that realization grounds their argument for the instrumental utility of birth control. Because unhealthy, unwise, and unwanted pregnancies can result from autonomous sex, birth control has great instrumental utility: it is, in

68. Alan Wertheimer, Consent to Sexual Relations 1-2 (2003); Alan Wertheimer, Consent and Sexual Relations, in Philosophy of Sex: Contemporary Readings 341, 342 (Alan Soble ed., 2002).

69. And well beyond, in my own view, any reasonable need to do so. Yes, all sex should be consensual. No, it doesn't follow from that, that all non-consensual sex should be criminal, or criminalized to the same degree. Non-consensual sex that is obtained through deceit that vitiates consent should not be criminal, and for the most part it isn't. And of course there should be degrees of criminality for the nonconsensual sex that is and should be criminal: some forms of nonconsensual sex are more harmful than other forms of nonconsensual sex. And yes, autonomous sex includes sadomasochistic sex that paradoxically has all the trappings of nonconsensuality - handcuffs, whips, chains and so on. Consensually enacted rape isn't rape anymore than its slavery. There's room for disagreement here, but perhaps less than contestants imagine. 
effect, a material condition for the autonomous heterosexual sex that they valorize. Contraception, then, is not just "not wrong." It is materially necessary for the realization of a natural human good: autonomous sex that is free of both reproductive consequences and free of the worry and fear of those consequences. Such sex is a positive good, and birth control is necessary to enjoy it. Sexual libertarians are not, in short, blind to the harms of harmful pregnancies, quite the contrary. Those harms are central to their brief for the instrumental value of birth control.

But, are there nevertheless harms attendant to autonomous sex, to which they are inattentive? I believe there are, and that they are almost never even acknowledged or named, much less addressed, within liberal and libertarian discourses on sex and sexual morality. There are two, and they echo the harms risked by marital sex. First, autonomous sex may be unwanted even if it is not rape, just as might marital sex. And second, autonomous sex might lead to unwanted pregnancy, either because of the failure of birth control, a decision not to use it for moral or financial reasons, or a failure to use it correctly because of recklessness or ignorance. I'll take up these two harms in that order.

First, autonomous sex, like marital sex, might be unwanted, and when it is, it might be harmful. A girl or woman may consent to sex with her boyfriend or partner for some of the same reasons a wife may consent to unwanted sex with her husband: she may consent to unwanted sex because she doesn't want to lose him or his affection, or because she doesn't want to risk the fight that will ensue if she doesn't, or because she is afraid of his future violence if she withholds consent, or because she wishes to keep domestic peace in her household if they cohabitate, or to protect her children from her his anger. A young woman or girl not involved in a long term relationship, may also consent to heterosexual sex she doesn't want for other reasons as well, not so obviously or so often shared with married women: she may consent to unwanted sex because she wrongly believes, out of simple naïveté, that the sex is unstoppable or "unavoidable" once her partner is aroused, or because she pities or likes her partner, or to impress her friends, or for the approval of or admission to a peer group, or, of course, because she thinks she needs to do so in order to get a good grade (or a raise) she may or may not deserve. According to a growing consensus among sex researchers, unwanted consensual sex, no matter how motivated, is extraordinarily common among sexually active college students of both sexes. They differ on the likelihood of the various motivations, but seemingly concur on the frequency of unwanted sex itself. ${ }^{70}$

70. See supra note 27. 
In the last fifteen years, some sociologists have begun to look at some of the harms caused by the sufferance of unwanted consensual sex, at least among college age women, as opposed to the harms caused by nonconsensual sex, or rape, which has been the subject of intense and extensive study for at least fifty years. The work is in its infancy, but it is growing. And, according to those studies, young, college-age women who engage in unwanted but consensual sex disproportionately suffer from depression and related psychological and emotional harms, they are less likely to use or insist upon birth control, so more likely to also suffer unwanted pregnancies, they have reduced self-esteem and sexual agency. These harms, furthermore, are likely to be long-lasting, they don't continue only for the duration of the sex itself, or the sexual relationship. ${ }^{71}$

Are there other harms incident to consensual but unwanted sex? I have speculated elsewhere that all of that unwanted consensual sex carry at least four distinctly psychic and even political harms, ${ }^{72}$ at least obliquely evidenced in one quite extraordinary unpublished qualitative study of unwanted sex by a Marxist-feminist scholar, ${ }^{73}$ and, much more explicitly, in some feminist memoirs. ${ }^{74}$ First, like the woman who carries an unwanted pregnancy, a woman or a girl's physical integrity and her sense of herself as having physical integrity, is invaded when she opens herself up, physically and literally, to penile penetrative sex she does not want and does not find pleasurable. Her body becomes, to that degree, fluid, or porous: she views her own body as boundariless in ways that are inconsistent with the conception of the boundaried body so central to liberal theory. ${ }^{75}$ Second, and again like the woman who bears an unwanted pregnancy, a woman or girl who consents to unwanted sex compromises her selfsovereignty: she willfully subjugates her body and her will to someone else's. She acts in ways inconsistent with her own desire, and not in

71. See Melanie J. Zimmer-Gembeck et al., Young Women's Satisfaction With Sex and Romance, and Emotional Reactions to Sex: Associations With Sexual Entitlement, Efficacy, and Situational Factors, 3 EMERGING Adulthood 113 (2015); Zoe D. Peterson \& Charlene L. Muehlenhard, Conceptualizing the "Wantedness" of Women's Consensual and Nonconsensual Sexual Experiences: Implications for How Women Label Their Experiences With Rape, 44 J. SEX RESEARCH 72 (2007).

72. West, Sex, Law and Consent, supra note 28, at 5; Susan F. Appleton, Toward a Culturally Cliterate Family Law, 23 BeRKeley J. GENDER L. \& JUST. 267 (2008).

73. Alyson Spurgus, Embodied Invisible Labor and Sexual Carework (unpublished manuscript) (on file with author).

74. See generally Andrea DWORKIn, InTERCOURSE (1988).

75. This is graphically and powerfully presented in Andrea Dworkin's masterful work Intercourse, $i d$. 
furtherance of her own pleasure. Again, the "self" she creates through these choices is in sharp contrast to the willing, choosing, and preferring "self" assumed by but also partly constructed by liberalism, who relentlessly chooses based on preferences that in turn track the subject's own, rather than another's, pleasures and pains. Her autonomy is likewise stunted, when she subordinates her own ends to those of another, and her self possession is threatened, when she applies her body to the work of providing a vehicle for someone else's pleasure. And lastly, her own moral integrity is undermined, if she lies to her partner and herself about her own pleasures or reasons for consenting to the sex she doesn't want. Physical integrity, autonomy, self-sovereignty, self-possession and integrity are all central components of the liberal, political self. When women and girls willfully relinquish them in their sexual lives, they are in effect relinquishing their entitlement to the enjoyment as well as the challenges of that widely lauded as well as widely expected-and intensely political - way of being in the social world.

These harms to selfhood could and should be characterized as at least potentially political, and not just psychic or emotional. A woman who routinely engages in unpleasant, unpleasurable, unwanted and unwelcome sexual intercourse, even if consensual, and whether or not marital, might come to regard herself, and others may regard her likewise, as being in effect the "kind of person" who has no physical integrity, and who might of course have pleasures and pains but whose pleasures and pains are irrelevant or marginal to her body's actions, and who may have and act on her own choices, but whose choices do not reflect her own desires, and who obviously has a body, but one which exists for the purpose of another's sexual fulfillment. As this becomes normalized and routinized, she may become that much less of a "liberal subject": a person who is prepared and presumed to interact in a world in which a subject's consent to actions, trades, bargains and institutions track the subject's preferences and her desires. She consents to all this sex, but that consent - her consent - does not, at least in a very important dimension of her life, track her own preferences and desires, rather than her partner's. This is a distinctive and quite different political harm than the harm done to a woman who has been raped: the woman who consents to unwanted sex is acting and experiencing herself as acting in a way that is contrary to the unity that we assume in the liberal self - a unity of desire and preference and choice, or act. The political harm of consensual unwanted sex, then, if this is right, is that the woman or girl's capacity to live as a "liberal self" is badly undercut. Quite plausibly, although again there's no research on this, at least that I can find, that might in turn limit both her viability and her potency in a liberal world hardly designed to accommodate someone so constituted. Consequently, she becomes an 
illiberal subject in a liberal world. It may not be quite so surprising that such illiberal women in liberal societies have a greater tendency toward self-abnegation, self denial, sacrifice and altruism than their more atomistic husbands, brothers, fathers and sons. It may not be so surprising, even, that they don't raise their hands in law school classes very often and that they aren't very adept at bargaining for a decent price when buying a used car. ${ }^{76}$ All of that unwanted sex to which they consent might be part of the problem, and for that reason alone, if no other, it should count as a harm. Again, the libertarian's valorization of autonomous sex is seemingly blind to it.

And finally, the libertarian's blanket celebration of autonomous and non-procreative sex covers not only harmful unwanted sex, but it also covers the autonomous sex, whether wanted or not, that leads to unwanted pregnancies: those pregnancies that occur when birth control fails, or - what is far more frequent-pregnancies that occur when it is not used because of oversight, ignorance, unavailability, or because of a moral belief in its wrongfulness. Unwanted pregnancies themselves, as argued above and as widely acknowledged, are clearly harmful in some recognized and objective ways: An unwanted pregnancy that may result from autonomous sex, no less than an unwanted pregnancy that may result from marital sex, may be carried to term, if the woman is opposed to or cannot afford an abortion or cannot access one, or it may be aborted, but either way, the pregnancy carries with it severe financial and health risks. Shari Motro has persuasively argued that these costs should be shared between the partners, whether they are cohabitating or casual. ${ }^{77}$ As with marital unwanted pregnancies, though, unwanted pregnancies caused by autonomous sex also carry the less recognized or at least less theorized psychic and political harms discussed above: an unwanted pregnancy, unlike a wanted pregnancy, is an unwelcome intrusion into and upon a woman's body by the life and needs of another human being, with attendant, and unwelcome, limits on her mobility, challenges to her health, and truncation of her selfpossession, autonomy and self-sovereignty. Her body exists, against her desires, for the interests of another, and her will follows suit.

Sexual libertarians obviously recognize at least some of the harms occasioned by unwanted pregnancies. Indeed, recognition of those harms is central to both the libertarian's argument for the right to use birth control and their argument for its dispensation: pregnancy

76. Ian Ayres \& Peter Siegelman, Race and Gender Discrimination in Bargaining for a New Car, 85 Am. ECON. REV. 304, 305 (1995); Carol M. Rose, Women and Property: Gaining and Losing Ground, 78 VA. L. REV. 421, 423 (1992).

77. Motro, supra note 33 . 
and the fear of pregnancy inhibit autonomous sex, autonomous sex is a natural good, and birth control is therefore of great instrumental value. But what sexual libertarians have not done is argue that the morality of autonomous sex, because of the pregnancy to which it may lead, is, precisely because of that risk, not unconditional. Nowhere, in libertarian, liberal or feminist arguments for either birth control or for legal abortion, is there even a suggestion that in the absence of reliable birth control, parties simply should not have sex. Nowhere in that voluminous literature is there a suggestion that uncontracepted autonomous sex, even if fully consensual, is harmful, and therefore both unwise and immoral, if the parties do not want to conceive. Nowhere is there a suggestion that by virtue of having sex when they are knowingly risking an unwanted pregnancy, they have therefore done something which is immoral or wrongful. Weirdly, all these unwanted pregnancies are immaculate conceptions: maybe they are harmful, but if they are, the sex is not to blame, rather, the law is.

By contrast, the harm of the unwanted pregnancy itself-as opposed to the harmfulness of the autonomous sex that causes it - is not at all invisible to the liberal imagination. Two prominent liberal legal scholars-Jed Rubenfeld from Yale Law School and Andrew Koppelman, from Northwestern-have argued over the last fifteen years that the harm of unwanted pregnancy is so profound as to be akin to the harms of slavery. ${ }^{78}$ Along with Eileen McDonagh's important work From Choice to Consent ${ }^{79}$ from the 1990s, and Judith Thompson's early 1970s philosophical defense of abortion, ${ }^{80}$ the Rubenfeld-Koppelman analogy captures better than most, the severity and the profundity of the harms occasioned by unwelcome or unwanted pregnancies. ${ }^{81}$ Nevertheless, what both Rubenfeld and Koppelman infer from their analogy of pregnancy to slavery, is not the wrongfulness of the autonomous sex that risks occasioning this crippling, enslaving harm. Rather, what both men infer from the harms they recognize in an unwanted pregnancy is the wrongfulness not of the sex that risks it, but of laws that would criminalize

78. See, e.g., Jed Rubenfeld, What Roe v. Wade Should Have Said 110 (Jack Balkin ed., 2005); Andrew Koppelman, Forced Labor Revisited: The Thirteenth Amendment and Abortion, in THE PROMISES OF Liberty: The History and Contemporary Relevance of the Thirteenth Amendment 229 (Alexander Tsesis ed., 2010).

79. Eileen L. McDonagh, From Choice to Consent (1996).

80. Judith Jarvis Thomson, A Defense of Abortion, 1 PHIL. \& PuB. AfF. 47 (1971).

81. RuBenfeld, supra note 78; Koppelman, supra note 78. 
abortion. ${ }^{82}$ The sex itself, for both theorists, gets off scot free. This is logically peculiar if nothing else. Surely the sex itself, and the decision to engage in it, and not just anti-abortion laws, is at least complicit in causing all those unwanted pregnancies, and the misery they in turn entail.

So, why? If unwanted pregnancy is wrong, and so wrong to be tantamount to slavery, then why isn't the heterosexual sex that causes it at least sometimes, and at least partly, to blame? Neither Koppelman nor Rubenfeld provide much by way of argument for their refusal to hold sex accountable. They do both suggest, though, albeit for the most part in footnotes and only very briefly, that to "blame the sex" - to suggest that the sex, and the assumption of the risk of pregnancy the decision to have sex entails - rather than the laws that criminalize abortion for the imposition of unwanted pregnancy (which, again, for both theorists, is tantamount to slavery) would be to wrongly suggest, or imply, that sex should be foregone where it would risk pregnancy. ${ }^{83}$ To blame the sex, rather than laws against abortion, for the unwanted pregnancy which sex occasions, would be in effect, to counsel for sexual abstinence. And that, they both say, is unrealistic, undesirable, or both. ${ }^{84}$ Sex is, first, just too good to be foresworn: to go through life without sex, Koppelman argues in a footnote, is simply unimaginable (although it isn't clear why he jumps to the life-long part).$^{85}$ Aside from its goodness, though, it is unrealistic to suggest that sex that might lead to an unwanted pregnancy should be foresworn: sex is inevitable. Sex is the result of forces-not the dark forces of Freudian imaginings, but forces nevertheless. They are quite literally impossible to control. Sex is unstoppable. There's no point in blaming the sex. The sex is going to happen regardless.

By virtue of this insistence, both theorists unwittingly underscore radical feminist skepticism about the motivation behind liberal arguments for abortion and birth control generally: that the availability of abortion is attractive to liberal men mostly because it frees women's bodies for male sexual use. Both theorists also give support to the beliefs of far too many teenage girls that they may as well consent to sex with an aroused partner even if they don't want it

82. $I d$.

83. See, e.g., Rubenfeld, supra note 40, at 789-790 n. 204.

84. See, e.g., Koppelman, supra note 39, at 1944.

85. Id. ("Those who resist the analogy should consider whether lifelong abstinence from sexual intercourse is something they would find unacceptable for themselves.") 
because the sex is inevitable in any event. The best that the state can do, if we take the teenage girls' beliefs on this score to be true, is to handle the fallout, which we can do by making abortions safe, legal and available. If we want to do something about the undesirability of the unwanted pregnancies that are the fully predictable consequence of sex that is inevitable (whether or not desired), the thing to do is to legalize, and then constitutionalize, the right to abortion. The rather different idea that we should respond to the specter of unwanted pregnancy by imposing upon the parties who want to have sex but who don't want to conceive a duty to either use contraception responsibly or not have sex would unfairly, or unrealistically, or both, limit the sexual franchise. With abortion made safe, legal and available, there is apparently no reason to further condition the morality of heterosexual sex, even if the consequence of all that sex for some women, in the absence of a right to an abortion, is a lived condition that is tantamount to slavery.

So, finally, why are the harms of autonomous sex-both the harms of unwanted sex itself and the harms of autonomous sex, whether wanted or not, that leads to unwanted pregnancies-so invisible within the libertarian conception of heterosexual morality? I think there is a host of reasons. First, and as I've argued briefly above, the very idea of "consensual harms," in some economically grounded versions of liberalism, is virtually oxymoronic: consent is widely regarded within economic liberal theory as the mechanism by which value is created, with the unfortunate consequence that consensuality is viewed as in effect precluding the visibility of harms that may be caused by any consensual transaction. ${ }^{86}$ Consensuality is also central to some non-economic libertarian as well as liberal feminist understandings of autonomy: consent itself is a sort of intrinsic as well as instrumental good. Sex, however, is also distinctively and peculiarly valorized within contemporary liberalism across the board, and so autonomous sex is all the more so: autonomous sex combines the value of consensuality with the value of sex. Sex, in the "liberal imagination," to borrow the expression from Stephen Macedo and Bradley and George's exchange, ${ }^{87}$ and as Tom Grey argued some time ago, ${ }^{88}$ is decidedly not the product of "dark

86. See generally West, supra note 42, at 399-400; West, Sex, Law and Consent, supra note 28, at 20; Robin West, The Harms of Consensual Sex, in Social Ethics: Morality And Social Policy 184, 184-85 (Thomas A. Mappes and Janes S. Zembaty, eds, McGraw-Hill, 2002).

87. George \& Bradley, supra note 11, at 306, responding to Macedo, supra note 14 .

88. Thomas C. Grey, Do We Have an Unwritten Constitution?, 27 Stan. L. REV. 703 (1975). 
forces," the repression of which makes civilization itself possible. Rather, sex, quintessentially, in the modern liberal imagination, contra Freud, is expressive, private, universal, a matter of taste, generative of pleasure, and imposes no or few costs on others. Sexual moralisms that assume to the contrary have imposed irrational and profound harms on vast swaths of the community, and for no sensible reason-as modern or contemporary liberals from Bertrand Russell ${ }^{89}$ to H.L.A. Hart ${ }^{90}$ to Michel Foucault ${ }^{91}$ to David Richards ${ }^{92}$ and to Stephen Macedo $^{93}$ have all in different ways argued. So long as consensual, there simply are no further conditions for the morality of autonomous sexuality. Therefore, the idea that sex also ought to be mutually desired as well as mutually consensual - not only in the workplace but everywhere - just doesn't enter the picture. Consent is moral condition enough. The harm, then, of unwanted but consensual sex is invisible, or at best made grey, to the sexual libertarian, no less than is the harm of unwanted marital sex to the natural lawyer.

The libertarian brief for birth control, and particularly its valorizing claim, is thus a mixed blessing. Obviously, birth control itself brings down the overall number of unwanted pregnancies from what it would be in a world in which the valorizing claim regarding sex had taken hold but without the technologies of reliable birth control. What's not so clear is whether it brings that overall number down below what it would be in a world in which the technologies are available and the valorizing claim had not taken hold. But whatever one might think of any of that, birth control itself surely doesn't bring

89. See generally Michel Foucault, The History of Sexuality: An InTrODUCTIOn 65 (Robert Hurley, trans., Random House, 1978); MiCHEL Foucault, The History of Sexuality: The Use of Pleasure 25-26 (Robert Hurley, trans., Random House, 1985); Michel Foucault, The History of SeXuality: The Care of the Self 39-40 (Robert Hurley, trans., Random House 1986).

90. See generally H.L.A. HART, LAW, Liberty, AND Morality 47 (1963) for a defense of restrictions against interference with private actions to counter Lord Patrick Devlin, The Enforcement of Morals (1968), which supported legal sanctions against morally unacceptable actions to preserve society's morality. The Hart-Devlin debate was spurred by the Report of the Departmental Committee on Homosexual Offences And Prostitution (1957) (known as the Wolfenden Report) recommending homosexual behavior between consenting adults in private should not be a criminal offense.

91. See generally Foucault, The History of SEXuality: AN Introduction, supra note 89; Foucault, The History of SeXuality: The Use of Pleasure, supra note 89; Foucault, The History of Sexuality: The Care of the Self, supra note 89.

92. RICHARDS, supra note 53, at 443-44.

93. See generally Macedo, supra note 14. 
down the overall number to the degree it would, were its use argued as a duty, and not just a right, by its most ardent defenders. And, obviously, birth control itself doesn't ameliorate at all the harms of the unwanted sex that the sexual libertarian's conception of sexual morality valorizes. Particularly when combined with the ideological and dogmatically valorizing conception of the value of autonomous sex that has fueled its availability, birth control might in fact worsen those harms.

The libertarian brief for birth control, no less than the natural lawyer's brief against it, is premised on a conception of heterosexual morality that runs roughshod over women's desires and women's pleasures both: the natural law conception does so by valorizing marital sex and the unwanted pregnancies it causes, and the libertarian's does so by valorizing autonomous sex, whether or not unwanted, and whether or not pleasurable, and by refusing to condition the morality of even wanted and pleasurable autonomous sex on the responsible use of birth control. Both natural lawyers and libertarians, in brief, valorize either pregnancies, or sex, or both, regardless of women's desire or lack of desire.

Does this matter? The harms caused by unwanted but either marital or autonomous sex, as well as unwanted but intentional pregnancy, whether marital or not, cannot in any obvious way ground lawsuits or crimes. Nevertheless, those harms, including the psychic and political harms occasioned by both unwanted sex and unwanted pregnancy, should be acknowledged and minimized. Instead, they are multiplying. And, they are intensified by one or the other of two conceptions of heterosexual morality to which almost all of us have more or less signed on, at least in the legal academy. The conclusion that follows comments briefly on how we might ameliorate the damage we've wrought.

\section{CONCLUSION}

Neither marriage nor the "marital form" of the sex that occurs within it guarantees that sex is mutually desired. But consent doesn't guarantee mutual desire either, no matter how consent is defined. In fact, one cost of the campaign for "affirmative consent" in our current conversations about rape is simply that it obscures this fact: the problem many women, and particularly young women, face with respect to sexuality is not that a man understands her passive acquiescence to sex as a yes while she understands it as a no, but rather, that she say "yes" so frequently-both passively and actively - to sex that she does not truly desire and does not want and from which she will take no pleasure. That problem is hardly clarified, and in fact it is obscured - and badly - by "yes means yes" campaigns. Likewise, though, abstinence-only campaigns, pushed 
aggressively (whether or not successfully) by moral conservatives as the best way to deal with social problems attendant to sex outside of marriage, don't in any way guarantee that the sex inside traditional marriages of the approved and celebrated reproductive form is also wanted. In fact, they obfuscate that problem, and for exactly the same reason: that a woman abstains from premarital sex doesn't mean that she wants particular sexual acts that occur within her marriage. The same is true of women's desires, pleasures, and interests with respect to pregnancy: pregnancies that result from either autonomous or marital sex can be unwanted, and when they are, they are harmful. Yet, women's sexual and reproductive desires, women's sexual and reproductive pleasures, and to a stunning degree, women's sexual and reproductive interests are simply irrelevant to the two conceptions of the morality of heterosexual sex that continue to define the poles of our cultural-sexual debates around birth control.

There is now little doubt that marriage does indeed make us happier, richer, healthier, and more long-lived, and it makes our children's lives happier, richer, healthier and more long-lived as well, as the institution of marriage's defenders and celebrants have long insisted. $^{94}$ Social conservatives have largely won the argument for the social utility of marriage. There is also now little doubt that the liberal's censorial claim regarding the necessity of consent to moral sex is a major advance for liberalism and women both. Nonconsensual sex is indeed always wrong (whether or not it is also always rape), and it is wrong whether or not the victim was a sex worker, whether or not she actively resisted, whether or not there was force employed, whether or not the parties were on a date, and whether or not they were married. Liberals have won that argument, and we're all-but particularly women-the better off for it. Nevertheless, neither consent nor marriage is sufficient to guarantee that sex is truly moral, no matter how consensual or how marital the sex. All sex, as well all the pregnancies all that sex sometimes causes, should be mutually wanted. When it is not mutually desired, it is harmful, and when both parties know that it is not desired by one or the other of them, it is immoral. A woman's desire is a necessary condition for the morality of the sex in which she engages, as well as for the morality of the pregnancy and maternity that may result. Neither marriage nor consent suffices.

The harms caused by deeply entrenched beliefs to the contrary should be addressed. The natural lawyer's conception of heterosexual morality - the blanket valorization of all uncontracepted penetrative sex within marriage - also implicitly valorizes unwanted sex and quite

94. For a full discussion, see generally Robin WeSt, MARRIAge, SEX AND GENDER (2007). 
explicitly valorizes the unwanted pregnancies that such sex (whether wanted or unwanted) may cause. To the extent that women live their sexual married lives on the basis of that belief, all of that uncontracepted marital sex presumably causes quite a few unwanted pregnancies. The libertarian's conception of heterosexual morality the blanket valorization of all autonomous heterosexual sex within or outside of marriage and the instrumental value attached to birth control accordingly -also valorizes unwanted autonomous sex as well. To the extent that women live their sexual lives on the basis of that liberal belief, all of that autonomous sex, when unwanted, carries unreckoned harms in its wake. Taking these harms seriously would require taking women's desires seriously as a moral condition of sex and reproduction both, whether inside marriage, with respect to the natural law conception, or outside of it, as per the liberal. That might be hard to do, in part, for the straightforwardly sexist reason that it is women more often than not who bear the brunt of those harms. To counter them requires us to reverse the course of millennia, and center rather than marginalize not just harms borne peculiarly by women, but also women's desires, including, most concretely, women's lack of desire, when they lack it, for heterosexual penetrative sex and for pregnancy both.

It shouldn't be so hard to do, though, either within a socially conservative milieu that honors the dignity and the sanctity of both women's and men's bodies, or in a liberal regime that honors their free will. The natural lawyer's insistence on the intrinsic moral value of heterosexual sex of the reproductive form could easily be amended to accommodate this simple moral fact: whatever one might think of the necessity of the reproductive form to moral sex and to the pregnancies that result, marriage and whatever "marital form" for sex one might wish to specify are clearly not sufficient conditions for the morality of marital sex. Mutual desire is a necessary condition of the morality of marital sex and of the pregnancies to which that sex sometimes leads. A woman's or a man's lack of desire for either sex or a pregnancy should be accorded moral veto power over the couple's decision to have sex, so as to minimize unwanted sex and unwanted pregnancy both. Even in a traditional relationship in which the use of birth control is off the table on moral grounds, the recognition of such a constraint would go some ways toward reducing both the amount of unwanted sex and the number of unwanted pregnancies within traditional marriages. A woman in an otherwise completely traditional marriage who only has sex when she affirmatively desires it, and who, during the periods in which she believes herself to be fertile, only when and if she also actively desires a pregnancy (rather than when she is open to a risk), will have less unwanted sex and fewer unwanted pregnancies simply by acting on those desires, and by insisting her partner does likewise. 
Just as clearly, the libertarian's valorization of autonomous sex stands in need of amendment: mutual desire, not just consensuality, is a necessary moral condition of both sex and the pregnancies that can result. Libertarians are surely correct to believe that the morality of consensual sex does not depend upon the marital status, or the gender, or the sexual orientation, much less the race or class of the parties engaging in it. But it does depend on mutual desire. A woman or girl who has consensual sex only when she feels a desire for it will have less unwanted sex and suffer fewer of its attendant harms than a woman or girl who does not do so. Likewise, a woman or girl who feels herself and her partner to be under a moral duty to use contraception when she wants the sex but not the pregnancy that may result, and has uncontracepted sex only when she affirmatively desires a pregnancy, will suffer far fewer unwanted pregnancies. Those are the behaviors we should be actively encouraging, both for our children and for ourselves: you don't just have a right to birth control under the Constitution, or a right to its availability under the ACA. You also have a moral duty to use it, or to abstain from sex if you do not want to become pregnant. And whether or not you're using birth control, you have a moral duty to your present and future self not to have sex when you don't want to, and not to impose it on an unwanting, even if consenting, partner. Finally, ought does indeed imply can: sex in point of fact is not inevitable, even when hotly desired. With that straightforward change in consciousness-that amendment to our liberal embrace of the positive value of autonomous sex - we'd all be better off. 